\title{
Valorization of Pozzolans as Partial Additive of Portland Cement: A Case of Pozzolans from the Localities of Foumbot, Penja and Tombel (Cameroon)
}

\author{
Mambou Ngueyep Luc Leroy ${ }^{1,2}$, Njimboum Aboubakar Sidiki², Tchakouteu Mbakop Théophile ${ }^{3}$, \\ Mache Jacques Richard ${ }^{4}$ \\ ${ }^{1}$ Laboratory of Materials Science, Department of Physics, Faculty of Science, University of Yaoundé 1, Yaoundé, Cameroon \\ ${ }^{2}$ Department of Mining \& Extractive Metallurgy, School of Geology \& Mining Engineering, University of Ngaoundéré, \\ Ngaoundéré, Cameroon \\ ${ }^{3}$ Laboratory of Applied Inorganic Chemistry, Faculty of Science, University of Yaoundé I, Yaoundé, Cameroon \\ ${ }^{4}$ Laboratory of Materials, Local Materials Promotion Authority, MINRESI/MIPROMALO, Yaoundé, Cameroon \\ Email: *mamboulucleroy@gmail.com
}

How to cite this paper: Leroy, M.N.L., Sidiki, N.A., Théophile, T.M. and Richard, M.J. (2019) Valorization of Pozzolans as Partial Additive of Portland Cement: A Case of Pozzolans from the Localities of Foumbot, Penja and Tombel (Cameroon). Journal of Minerals and Materials Characterization and Engineering, 7, 18-33. https://doi.org/10.4236/jmmce.2019.71002

Received: December 8, 2018

Accepted: January 18, 2019

Published: January 21, 2019

Copyright () 2019 by author(s) and Scientific Research Publishing Inc. This work is licensed under the Creative Commons Attribution International License (CC BY 4.0).

http://creativecommons.org/licenses/by/4.0/

\begin{abstract}
The objective of this study is to find alternative materials that can be used as an addition in cement in order to produce ecological and economical cement. Three pozzolans coming from different volcanic regions of Cameroon (Penja, Tombel and Foumbot) were sampling. Mechanical compressions on $40 \times 40$ $\times 160 \mathrm{~mm}^{3}$ mortar specimens were made with partial replacements of $2 \%$, $4 \%, 6 \%$ and $8 \%$ of the pozzolans in Portland cement and physical analyzes on the mortar powders were carried out. The values of the activity indices of different pozzolans obtained are in the normative range. The compressive strength of motars decreases at all ages with the proportion of cement substitution. The compressive strength values up to $40 \mathrm{Mpa}$ are obtained for a substitution of $6 \%$ for the pozzolans from Penja, Tombel and $8 \%$ for the pozzolan from Foumbot. Pozzolan from Foumbot which contains the highest percentage of $\mathrm{SiO}_{2}$ offers a maximum substitution rate and therefore optimally reduces the production costs of Portland cement. Physical tests show that specific surfaces increase with an additions of pozzolans from Tombel and Penja.
\end{abstract}

\section{Keywords}

Pozzolan, Mortars, Compressive Strength, Tensile Strength

\section{Introduction}

Concrete is a mixture of material made up of aggregates (fine and coarse), water, 
cement and additives. Its mechanical performance, fire resistance and competitive cost are properties that make it one of the most widely used building materials in the world [1].

The cement industry is involving in various strategies to limit, mitigate and minimize the production impacts on the ecosystem. In terms of strategy, we can note, among other things, the optimization of production processes, the modernization of cement kilns and the replacement of traditional fossil fuels used for the benefit of renewable energies and industrial waste. The implementation of these solutions, among others, has allowed the cement industry to reduce by $20 \%$ of $\mathrm{CO}_{2}$ emissions per ton of cement for the period 1990-2000 [2].

Another strategy would be to find scientific solutions to limit the $\mathrm{CO}_{2}$ emissions generated by the clinker manufacturing process. Materials with chemical and mineral compositions comparable to those of clinker seem to occupy a prominent place. They are grouped under the name pozzolanic materials [3] and used as partial substitutes for clinker. They are of natural origin or industrial waste [4]. In the literature, the most commonly used pouzzonlanic products are silico-aluminous or sulpho-calcic fly ash, silica fumes, high-furnace slags, sulfoalumin, metakaolin, sugar cane, etc. [5]. This substitution allows the realization of many cement matrixes and thus diversifies the performance, quality and use of the finished product that is cement. The work done by Gumma et al. [6] shows that the use of natural pozzolana as a partial substitution makes it possible to increase by $20 \%$ of the compressive strength of the mortar for a substitution of $20 \%$ by the weight of cement. Similarly, Mbessa et al. [7] show that natural pozzolana powder can effectively substitute up to $20 \%$ of cement without reducing the strength class of this cement. Volcanic scoria deposits are abundant in Cameroon. Cameroon has been affected by a gigantictectonic accident linking the Sao Tome and will continue until the Tibesti [8]. This accident is observed by the alignment of forty massifs over a distance of more than $500 \mathrm{~km}$, from the Atlantic Ocean to Lake Chad which is called the "Cameroon Volcanic Line" (CVL). The CVL is a suite of volcanic and sub volcanic devices, that are aligned in the direction North $30^{\circ}$ East. $1600 \mathrm{~km}$ long, it is dotted with volcanic massifs of the Southwest to Northeast. It comprises Gulf of Guinea islands, mostly volcanic: Bioko Pagalu, Sao Tome, Principe and also some seamounts; the region of West Cameroon, with alternating mountains: Mount Cameroon (Altitude: 4100 $\mathrm{m}$ ), the Manengouba Mountains (shield volcano of $20 \mathrm{~km}$ in diameter, with no known historic activity presents some Strombolian cones Bamboutou, Mbam and Oku and grabens (Kumba, Tombel, Mamfe, Mbos and Ndop) and end the Tikar lowland (Foumban in Banyo) [8].

These materials are in general very little used as an addition for the manufacture of composite Portland cement, the reinforcement of certain unpaved roads or as an aggregate for the formulation of concretes. Volcanic slags or natural pozzolans are fragments of low density vesicular magma and are projected during volcanic explosions [9]. The ability to use these materials in their natural state can be an important economic asset for countries with abundance of those 
materials. Many works have investigated and characterized some pozzolans found in Cameroon and their applications in civil engineering [8]-[23].

In 2008 Demirdag et al. [13] investigated the control lightweight concrete (CLC) mixtures containing volcanic slag aggregates (VSA) with only normal portland cement (NPC) and finally with fly ash lightweight concrete (FALC) mixture containing $20 \%$ of FA as a replacement of the cement by volume.

Their research showed that, masonry units having desired properties can be produced by using fine and coarse VSA lightweight aggregate in the mixture with $10 \%$ cement by volume.

In 2009 Kaid et al. [14] studied the application of a performance-based approach on the durability of concrete made with an Algerian natural pozzolan. The evaluation of the durability of concrete was based on the comparison of durability indicators with a reference concrete usually found in Algeria. The results of specific indicators for corrosion and acid attacks showed that increasing the pozzolan content led to higher resistance of the concrete. Thus, it is possible to improve the durability of typical concretes currently made in Algeria by using local materials.

In 2011 Siddique [15] analysed the comprehensive details of the physical, chemical properties of volcanic ash, and its micro-structure and hydration products. It also covers effect of volcanic ash on consistency, setting times, workability, compressive strength, electrical resistivity of cement paste and mortar.

In 2013 Tchakouté et al. [16] characterized two types of volcanic ash (chemical and mineralogical compositions, amorphous phase composition, particle size distribution and specific surface area) and then used as raw materials for the synthesis of geopolymer cements cured at ambient temperature $\left(24^{\circ} \mathrm{C} \pm 3^{\circ} \mathrm{C}\right)$. The volcanic ash sample with large $\left(\mathrm{Al}_{2} \mathrm{O}_{3}+\mathrm{SiO}_{2}\right) \%$ wt of amorphous phase, high specific surface area $\left(15.7 \mathrm{~m}^{2} / \mathrm{g}\right)$ and synthesized products with $\mathrm{Na}_{2} \mathrm{O} / \mathrm{Al}_{2} \mathrm{O}_{3}$ molar ratios between 1.04 and 1.31 led to more effective geopolymers: setting time was between 490 and $180 \mathrm{~min}$ and 28-day compressive strength between 23 and $50 \mathrm{MPa}$ at ambient curing temperature $\left(24^{\circ} \mathrm{C} \pm 3^{\circ} \mathrm{C}\right)$.

In $2014 \mathrm{Kemal}$ et al. [17] compared the effects of Portland cement replacement on the strength and durability of self-consolidating concretes (SSC). The two replacement materials used are high-volume natural pozzolan (HVNP), a Saudi Arabian aluminum-silica rich basaltic glass and high-volume Class-F fly ash (HVFAF), from Jim Bridger Power Plant, Wyoming, US. The HVNP and HVFAF concrete mixes showed strength and durability results comparable to those of the reference concretes; identifying that both can effectively be used to produce low-cost and environmental friendly SCC.

In 2015 Kilic et al. [18] evaluated the suitability of finely ground $(-20 \mu \mathrm{m})$ and/or heated $\left(\right.$ at $1000^{\circ} \mathrm{C}$ ) volcanic pumice powder to be used as a supplementary cementitious material. The results from their study showed that the heat treatment significantly affected the pozzolanic activity of VP, and use of heated-ground pumice as a supplementary cementitious material increased the strength of mortar 
up to $7 \%$ in 90 days as well as 7- and, 28-day strengths.

In 2016 Djobo et al. [19] evaluated the mechanical properties and durability of volcanic ash based geopolymer mortars synthesized at $27^{\circ} \mathrm{C}$ and $80^{\circ} \mathrm{C}$. Their results showed that the pore structure and permeability are the key factors affecting the durability of volcanic ash based geopolymer mortars.

In 2017 Zhang et al. [20] manufactured the fired hollow clay bricks (FHCBs) by firing a type of highly expansive soils, the black cotton soil (BCS), and natural volcanic ashes (VA), which were both collected from Kenya. This research provides a strategy in making use of vast resources BCS in Kenya obtained from municipal constructions.

In 2017 Djobo et al. [21] investigated the role of chemical composition and mineral contents of volcanic ash on their reactivity during geopolymerization reaction and, consequently, mechanical properties.

Their works showed that there are still many works such as durability tests (carbonation, freeze-thaw, resistance, etc.), life cycle analysis, etc. that need to be done in order to satisfy both suitability and sustainability criteria for a large-scale or industrial application.

In 2018 Kupwade-Patil et al. [22] studied the effect on Embodied Energy (EE) of concrete when Ordinary Portland Cement (OPC) is partially substituted with natural Pozzolanic Volcanic Ash (VA) at the material and the building scale. The work aims to demonstrate potential improvements to the EE of buildings by comparing the $\mathrm{EE}$ of the cement mix with VA replacement to that of baseline case of traditional concrete. The demonstrated reduction in EE values were calculated when natural supplementary cementitious materials (SCM) such as volcanic ash are used as a partial replacement to OPC, and it can be adapted to design and build energy-efficient systems tailored for structural and non-structural applications.

Recently in 2018 Lemougna et al. [23] summarized the main interesting research outcomes on volcanic ashes in the fields of cements and concretes, geopolymers, ceramics, low grade refractory materials, lunar soil stimulants and adsorbents. Factors affecting their suitability for specific applications are screened and possible areas of interest for future research suggested.

However few of them have made a comparative study between the pozzolans of the different regions of Cameroon is done, in order to choose the best pozzolanas additive for producing economical and ecological cement. The objective of this workis to assess the pozzolanic response of volcanic ash from the volcanic areas of Penja, Tombel and Foumbot and then compare their contribution in the development of composite cements while contributing to reduce pollution due to cement production.

\section{Materials and Experimental Methods}

\subsection{Materials}

\subsubsection{Clinker and Gypsum}

Clinker and gypsum used in this paper are coming from DANGOTE Cameroon 
cement Factory in accordance with the standard ASTM C150-07 [24].

\subsubsection{Natural Pouzzolona}

The different pozzolans are from volcanic eruptions and they have black color. They are coming from the localities of Foumbot (Fpo), Penja (Pjpo) and Tombel (Tpo) all respectively located in the West regions (Mount Mbapit), the Littoral (Mount Koupé), and the Southwest (Mount Cameroon). Figure 1 shows the pozzolan sampling map.

The different pozzolans were firstly characterized in order to determine their chemical composition and physical properties. The different samples were obtained by a quartering and grinding process in a ball mill for a grinding time of 4 hours followed by a particle size analysis using a 45 microns sieve.

\subsubsection{Cement}

The cement used for this study is ordinary Portland cement type $42.5 \mathrm{R}$ of the company Dangoté Cameroon in accordance with the standard ASTM C150-07 [24]. It consists only of clinker (95\%) and gypsum (5\%).

\subsubsection{Sand}

The sand used is standardized sand. It complies with ASTM C-128 [25].

\subsubsection{Water}

The water used comes from the analysis laboratory. It is generally used for making concrete.

\subsection{Methods}

\subsubsection{Preparation of Samples}

Volcanic ash from Foumbot, Tombel and Penja was used as a partial substitute

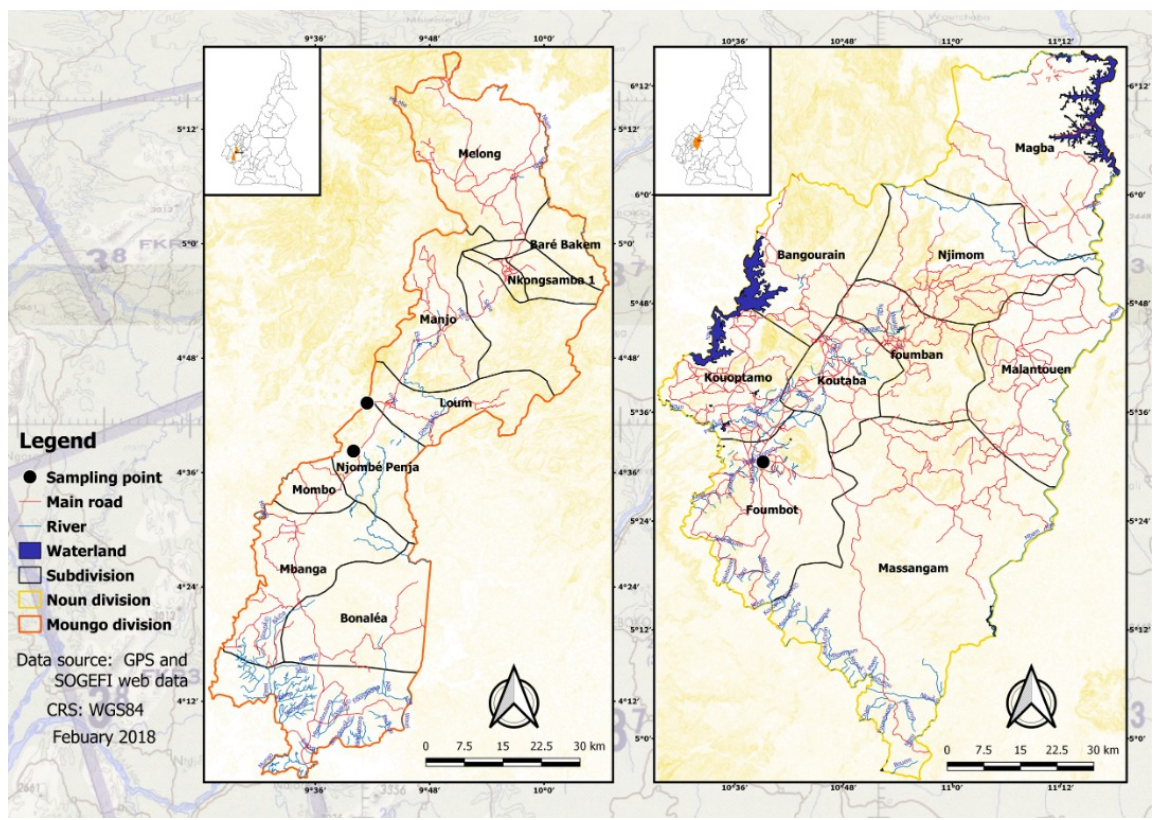

Figure 1. Sampling map of different pozzolans. 
for $2 \%, 4 \%, 6 \%$, and $8 \%$ of clinker by the weight of cement. The cement-sand ratio $(\mathrm{C} / \mathrm{S})$ has been kept constant at $1 / 3$ and the water-cement ratio $(\mathrm{W} / \mathrm{C})$ at 0.5 . In order to determine the compressive and flexural strengths, different mortars were made in accordance with ASTM C618 [26] and stored in a water bath at room temperature of $20^{\circ} \mathrm{C} \pm 1^{\circ} \mathrm{C}$. The flexural and compressive strength tests were carried out at 7, 14 and 28 days, according to the EN 196-1 standard [27] for compression testing procedures on cement mortars.

\subsubsection{Consistency Tests}

The consistency test is carried out with the Vicat machine. The test is carried out in an air conditioned room maintained at $20^{\circ} \mathrm{C} \pm 2^{\circ} \mathrm{C}$ and at a relative humidity of at least $65 \%$. This test was carried out on cement paste according to the European standard EN 196-3 [28].

\subsubsection{Setting Time Test}

The sampling tests are done using the Vicat needle which gives two practical references: the initial setting and final setting time. This test was carried out on cement paste according to the European standard EN 196-3 [28].

\subsubsection{Mortars}

These mortars are made up according to EN 196-1 [27]. Mortar is the mixture of sand and cement composed in a proportion of $1: 3$ with a $\mathrm{W} / \mathrm{C}$ ratio $=0.5$.

Mortar specimens of $40 \times 40 \times 160 \mathrm{~mm}^{3}$ were manufactured and formulated with partial replacements of $2 \%, 4 \%, 6 \%$ and $8 \%$ of pozzolans in portland cement.

\subsubsection{Mechanics Strengths}

The mechanical compression tests were carried out on $40 \times 40 \times 160 \mathrm{~mm}^{3}$ mortar specimens. Compressive strength of the cube was measured by compression testing machine (Perrier) having a capacity of $6000 \mathrm{kN}$ at the age of 7, 14 and 28 days. For each mixture three specimens were tested and tests were carried out according to the relevant IS standards.

\section{Results and Discussions}

\subsection{Physical, Chemical and Mineralogical Properties of Materials}

The chemical compositions of pozzolans are shown in Table 1.

The mineralogical analysis of these different pozzolans shows that pozzolan from Foumbot (FPo) have the highest percentage of $\mathrm{SiO}_{2}$ followed by pozzolan from Penja and pozzolan from Tombel. It can be noted that for pozzolans from Foumbot and Penja, \% $\left(\mathrm{Al}_{2} \mathrm{O}_{3}+\mathrm{SiO}_{2}+\mathrm{Fe}_{2} \mathrm{O}_{3}\right)>70 \%$ then, these volcanic ashes can be used as pozzolanic materials. All these materials have semicrystalline phases and amorphous phases.

Figures 2-4 show XRD of different pozzolans.

The XRD analysis of the pozzolans (see Figure 1 and Figure 2) shows that other than the amorphous phase, the crystalline phases presented in the pozzolans 


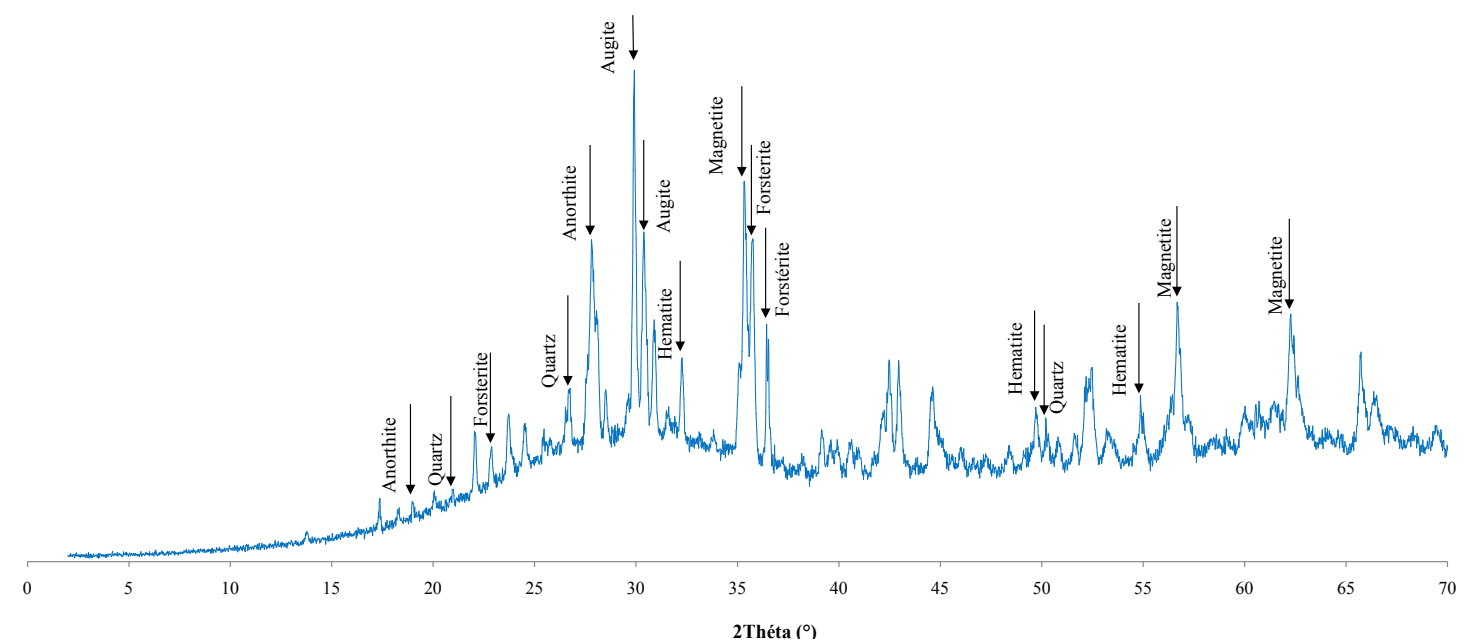

Figure 2. XRD of pozzolans from Foumbot.

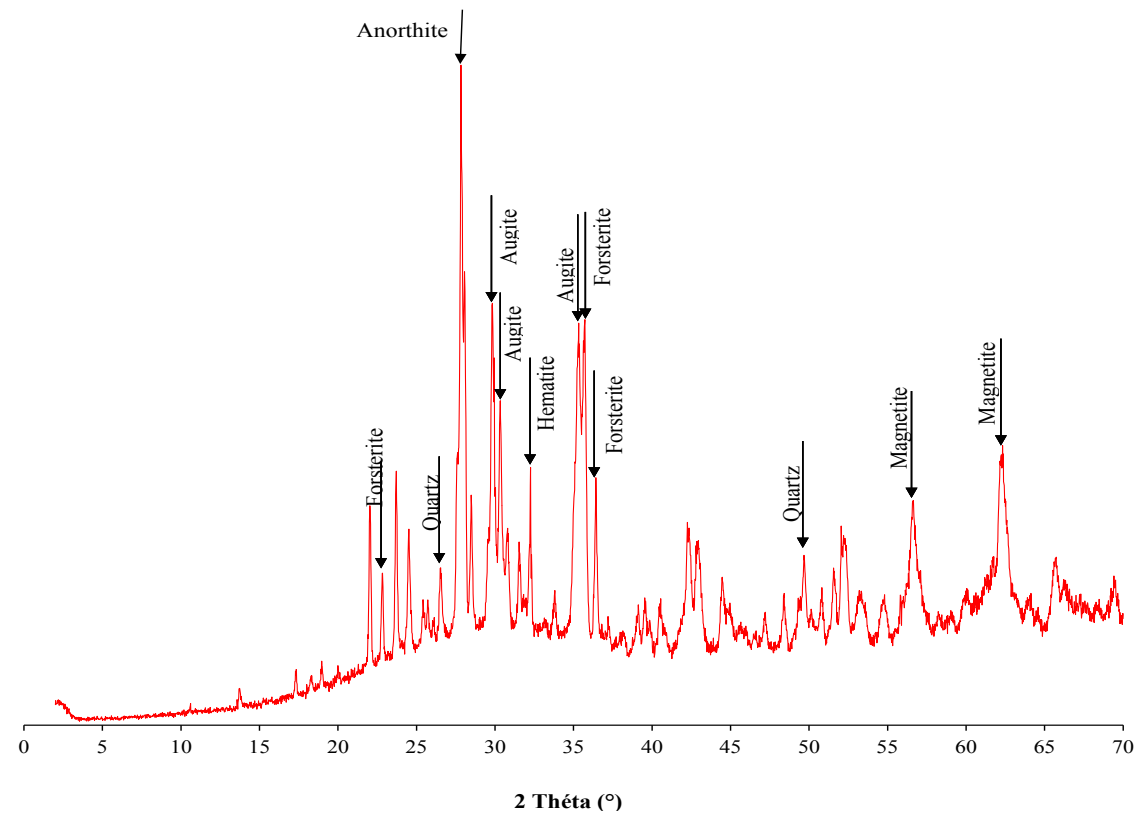

Figure 3. XRD of pouzzolans from Penja.

Table 1. Chemical composition of pozzolans from Tombel, Foumbot and Penja.

\begin{tabular}{cccc}
\hline Oxyde (\%) & TPo & FPo & PjPo \\
\hline $\mathrm{SiO}_{2}$ & 32.61 & 55 & 43 \\
$\mathrm{TiO}_{2}$ & 5.78 & 1.8 & 3.3 \\
$\mathrm{Al}_{2} \mathrm{O}_{3}$ & 12.48 & 15 & 15 \\
$\mathrm{Fe}_{2} \mathrm{O}_{3}$ & 22.65 & 8.5 & 14 \\
$\mathrm{MgO}$ & 6.58 & 2.9 & 5.8 \\
$\mathrm{CaO}$ & 13.58 & 6.1 & 11 \\
$\mathrm{~K}_{2} \mathrm{O}$ & 1.01 & 3.1 & 1.7 \\
$\mathrm{Na}_{2} \mathrm{O}$ & 1.16 & 5.3 & 4.1 \\
$\mathrm{SO}_{3}$ & 0.18 & 0.9 & 0.8 \\
\hline
\end{tabular}




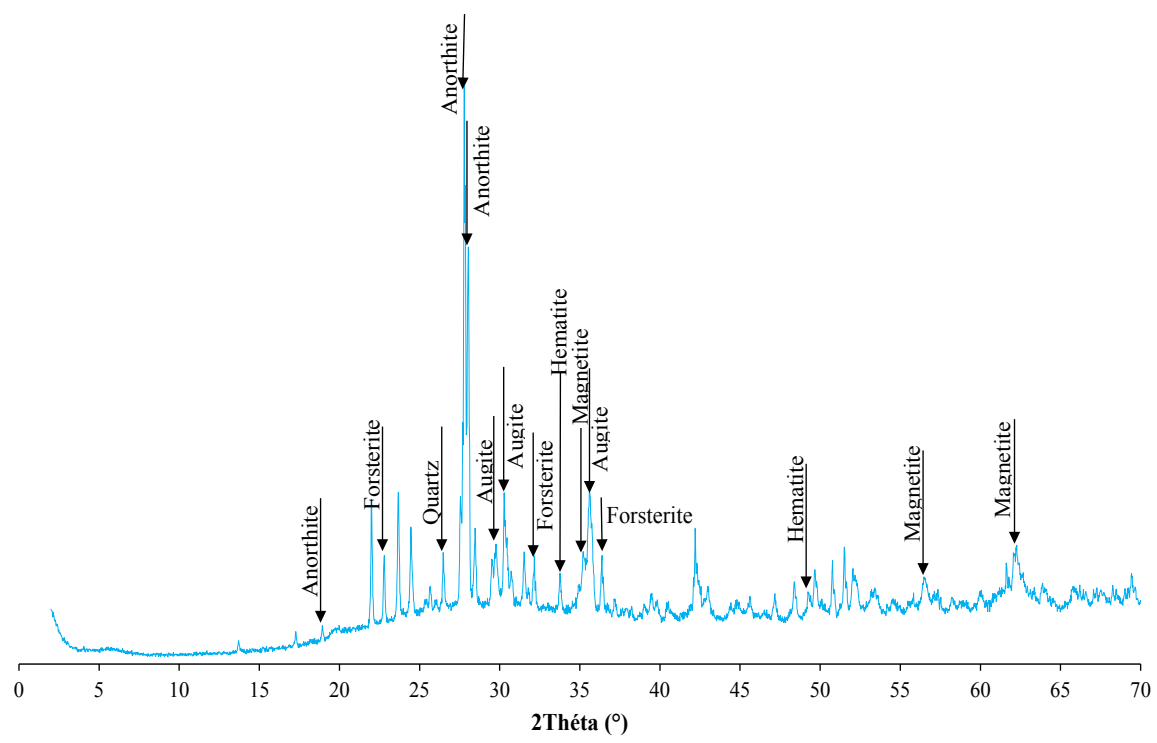

Figure 4. XRD of pozzolans from Tombel.

were calcite, gypsum, anhydrite, quartz, tridymite, magnetite, hematite, rutile, muscovite, and some evidence of portlandite.

The XRD of pozzolans presents high quantity of amorphous phase (Figures $2-4)$. This is probably due to the nature of such materials that result from rapid cooling of volcanic lavas [9]. The peak identification shows common minerals for all pozzolans as diopside, enstatite, anorthite, albite and quartz.

\section{1) Specific Surface}

The specific surfaces of pozzolans from Foumbot, Penja and Tombel are designated as SSF, SSP, SST, respectively was determined in accordance with ASTM C 618 [12].

The various results obtained are summarized in Table 2.

The highest specific surface at $6 \%$ to $8 \%$ of addition is obtained with pozzolanfrom Foumbot followed by Pozzolan from Penja.

\section{2) Activity Index}

Figure 5 shows the evolution of the activity index (Id) obtained at 28 days as a function of the degree of substitution in weight of cement by different pozzolans.

In Figure 5 , it is noted that at 28 days of age, from $0 \%$ to $8 \%$ of addition, activity indices of all pozollan are above $80 \%$. Allthese values are above the normative limit (67\%), we can conclude that all these pozzolans have pozzolanic material. We also observe a decreasing of the activity index when the percentage of addition increases. It goes from $90 \%$ for $2 \%$ of addition for pozzolans from Foumbot and Tombel to $86 \%$ for $8 \%$ of addition and $81 \%$ for $8 \%$ of addition of pozzolan from Tombel. Then we can conclude that, the black pozzolan from Foumbot could presents better mechanical results, followed by pozzolan from Penjaand finally pozzolan from Tombel

\subsection{Mechanical Results}

1) Case of Pozzolan from Foumbot 
Table 2. specific surface.

\begin{tabular}{cccccc}
\hline Mixture proportion of pozzolana & $0 \%$ & $2 \%$ & $4 \%$ & $6 \%$ & $8 \%$ \\
\hline SSF $\left(\mathrm{g} / \mathrm{cm}^{2}\right)$ & 2986 & 3210 & 3420 & 3567 & 3650 \\
SST $\left(\mathrm{g} / \mathrm{cm}^{2}\right)$ & 2986 & 3212 & 3345 & 3461 & 3502 \\
SSP $\left(\mathrm{g} / \mathrm{cm}^{2}\right)$ & 2986 & 3230 & 3335 & 3542 & 3632 \\
\hline
\end{tabular}

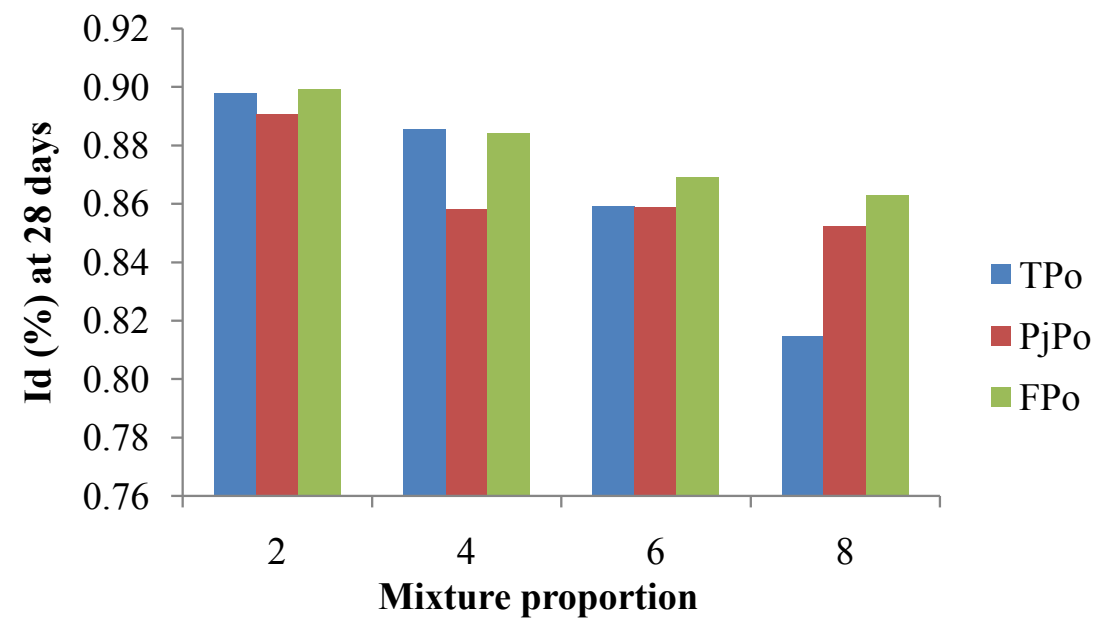

Figure 5. Activity index as function of the percentage of addition.

The consistency tests were carried out on cement pastes formulated from cements manufactured by adding black pozzolan from Foumbot according to European and Cameroonian standards. The results of the consistency and setting tests are recorded in Table 3.

In Table 3, it can be seen that the initial setting time decreases with the percentage of addition of the pozzolan.

The rate of hydration for the initial setting time is fast. However, the final setting time curve increases with the percentage of pozzolan addition. This can be explained by the fact that the rate of hydration decreases the reaction time of pozzolan, which has a long-term effect.

Figure 6 and Figure 7 show the evolution of the compressive strength and tensile strength of mortars containing a variable rate of additions of natural pozzolana $(2 \%, 4 \%, 6 \%$ and $8 \%)$ at different ages: 7,14 and 28 days.

Figure 6 and Figure 7 show that the compressive strengths and tensile strength decrease with the addition rate of $2 \%, 4 \%, 6 \%$ and $8 \%$ at 7,14 and 28 days respectively. At 28 days, we see that all mortars formulated with the addition of Foumbot black pozzolan have resistances that remain within the standard range of $40 \mathrm{MPa}$. Therefore the addition to $8 \%$ of this pozzolan in the manufacturing of cement can be recommended.

\section{2) Case of Black Pozzolan from Penja}

The results of the consistency and setting tests are shown in Table 4.

In Table 4, we observe a decreasing of the setting start time with the rate of addition. This is due to a rapid rate of hydration of the cement paste. We also 


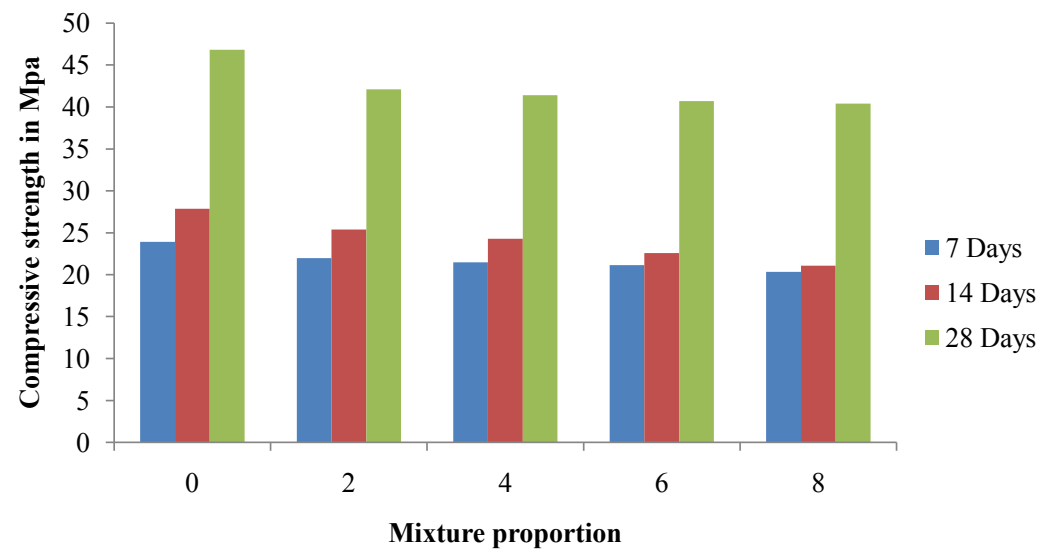

Figure 6. Compressive strength of mortars as function of percentage of addition: case of Foumbot pozolans.

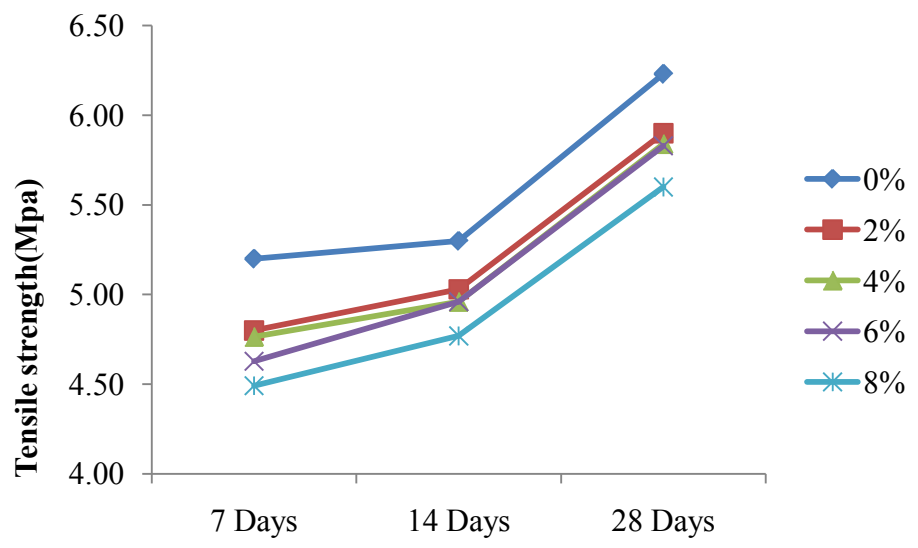

Figure 7. Tensile strength of mortars as function of percentage of addition: case of Foumbot pozolans.

Table 3. Consistency and setting time of black pozzolan from Foumbot.

\begin{tabular}{ccccc}
\hline Désignation & $\begin{array}{c}\text { \% mixture } \\
\text { proportion }\end{array}$ & Consistency (\%) & $\begin{array}{c}\text { Initial setting time } \\
\text { (minutes) }\end{array}$ & $\begin{array}{c}\text { Final setting time } \\
\text { (minutes) }\end{array}$ \\
\hline CEM II B & 0 & 28 & 146 & 349 \\
FPo & 2 & 28 & 140 & 352 \\
FPo & 4 & 28 & 133 & 394 \\
FPo & 6 & 28 & 125 & 388 \\
FPo & 8 & 28 & 123 & 386 \\
\hline
\end{tabular}

Table 4. Consistency and setting time of black pozzolan from Penja.

\begin{tabular}{ccccc}
\hline Désignation & \% mixture percentage & Consistency (\%) & Initial setting time & Final setting time \\
\hline CEM II B & 0 & 28 & 148 & 349 \\
PjPo & 2 & 28 & 142 & 352 \\
PjPo & 4 & 28 & 137 & 394 \\
PjPo & 6 & 28 & 136 & 388 \\
PJPo & 8 & 28 & 129 & 386 \\
\hline
\end{tabular}


notice an increase of the final setting time for an addition of $0 \%$ to $4 \%$ of addition, which shows that the rate of hydration is slow for this interval of addition of the black pozzolan from Penja. From $4 \%$ to $8 \%$ of pozzolan addition, we notice a clear decrease of final setting time, which causes a decrease in the speed of hydration. For the low values of adding black pozzolan from Penja, we observe that it has a delaying effect.

Figure 8 and Figure 9 show the compressive and tensile strength of mortars as function of percentage of addition: case of pozolan from Penja

In Figure 8 and Figure 9, it is noted that the compressive strengths decrease with the addition rate of $2 \%, 4 \%, 6 \%$ and $8 \%$ compared to the control mortar at 7,14 and 28 days in succession.

At 28 days, we note that the resistance of the mortars with an addition of $8 \%$ pozzolan is less than $40 \mathrm{MPa}$ at 28 days. For the additions of $2 \%, 4 \%$ and $6 \%$ the resistances obtained are greater than $40 \mathrm{MPa}$. Therefore an addition from $2 \%$ to $6 \%$ of this pozzolan in the manufacturing of cement can be recommended.

\section{3) Case of Pozzolan from Tombel}

The results of the consistency and setting tests are shown in Table 5 and Figure 13.

In Table 5, we observe an increasing of the initial setting time with the pozzolan addition rate. This is due to a slow rate of hydration of the cement paste. Moreover, the final setting time decreases with the addition rate of pozzolan, which can be attribute to the low speed of hydration of the cement paste is slow.

Figure 10 and Figure 11 present compressive strength and tensile strength as function of percentage of addition in the case of Tombel pouzzolan.

For all ages of 7, 14 and 28 days, the compressive strength and tensile strength decrease with the rate of addition of pozzolan. At 28 days, it is noted that the resistance of the mortars with addition of $8 \%$ pozzolan is lower than the norm which stipulates that the acceptable limit is $40 \mathrm{MPa}$ (compressive strength) at 28 days for a cement to be validated. While additions of $2 \%, 4 \%$ and $6 \%$ additions are still in the cement class since their strengths are greater than $40 \mathrm{MPa}$. According to these results, we can propose an addition of the range of 0 to $6 \%$ of the black pozzolan from Tombel for the manufacturing of cement in order to reduce the cost of cement.

4) Comparative Study of Compressive and Tensile Strengths at 28 Days of Age for Different Pozzolans

Table 5. Consistency and setting time of black pozzolan from Tombel.

\begin{tabular}{ccccc}
\hline Designation & Mixture proportion & Consistency (\%) & Initial setting time & Final setting time \\
\hline CEM II B & 0 & 28 & 153 & 445 \\
TPo & 2 & 28 & 168 & 445 \\
TPo & 4 & 28 & 168 & 446 \\
TPo & 6 & 28 & 171 & 441 \\
TPo & 8 & 28 & 180 & 432 \\
\hline
\end{tabular}




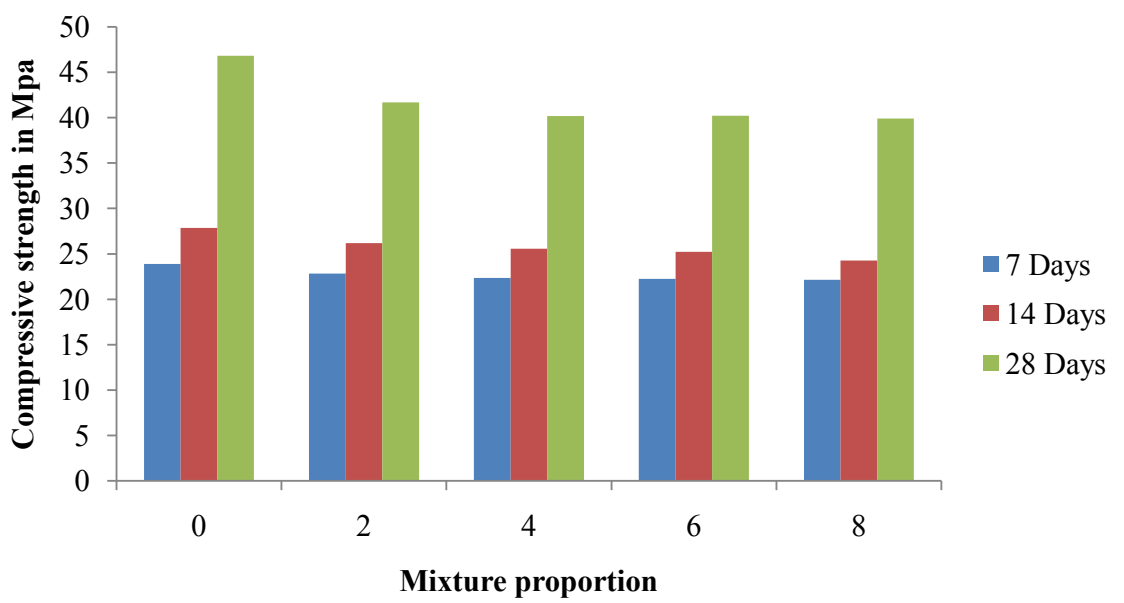

Figure 8. Compressive strength of mortars as function of percentage of addition: case of pozolans from Penja.

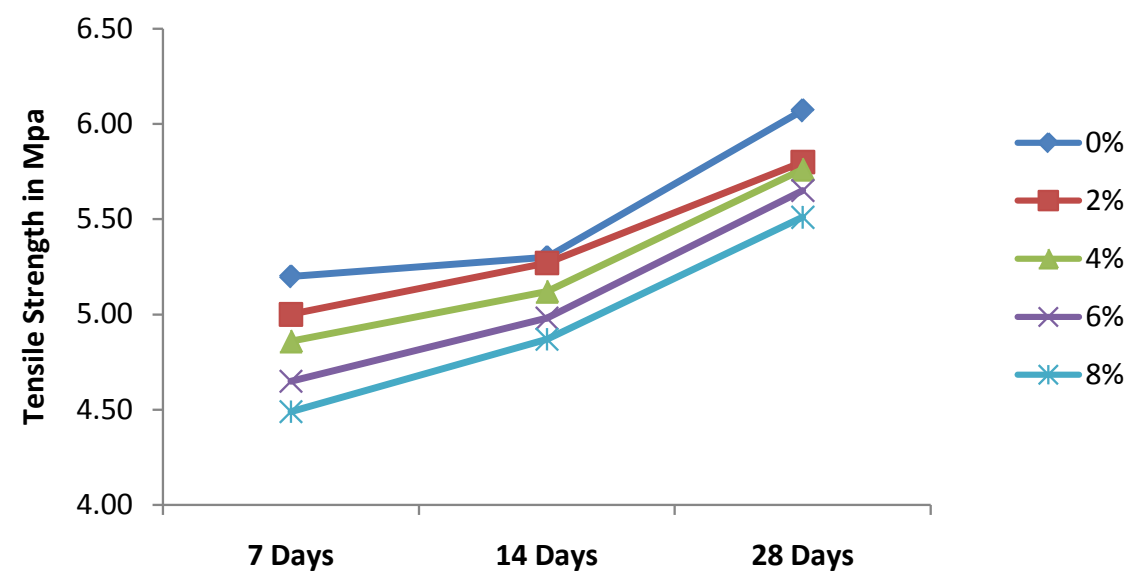

Figure 9. Tensile strength of mortars as function of percentage of addition: case of pozolans from Penja.

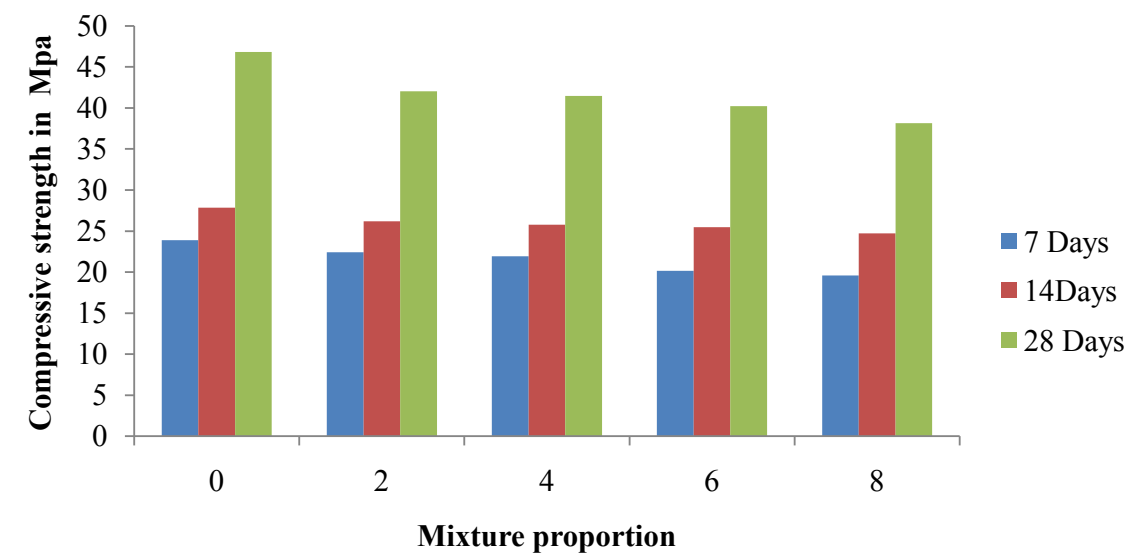

Figure 10. Compressive strength of mortars as function of percentage of addition: case of pozolans from Tombel.

Figure 12 and Figure 13 show the results of compressive and tensile strength obtained at 28 days for different pozzolans studied. 


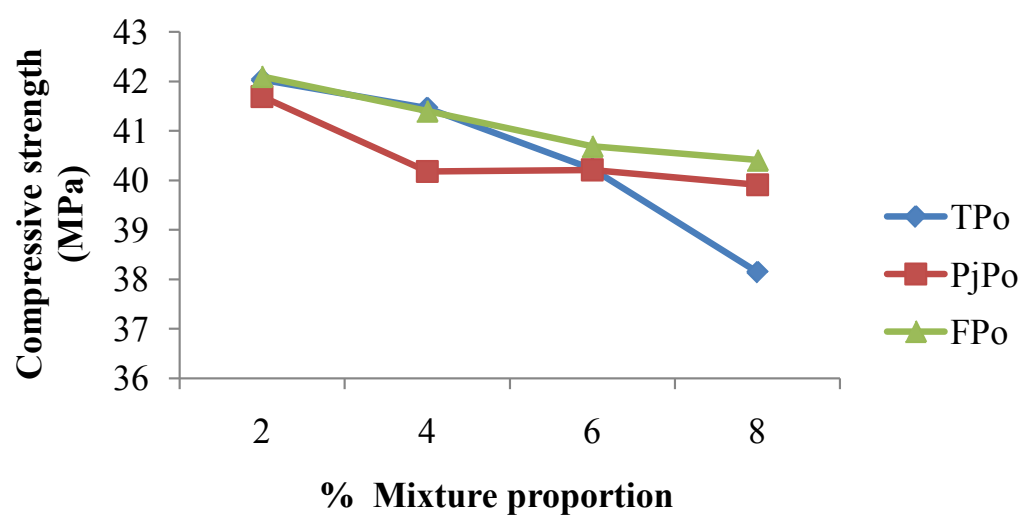

Figure 11. Tensile strength of mortars as function of percentage of addition: case of pozolans from Tombel.

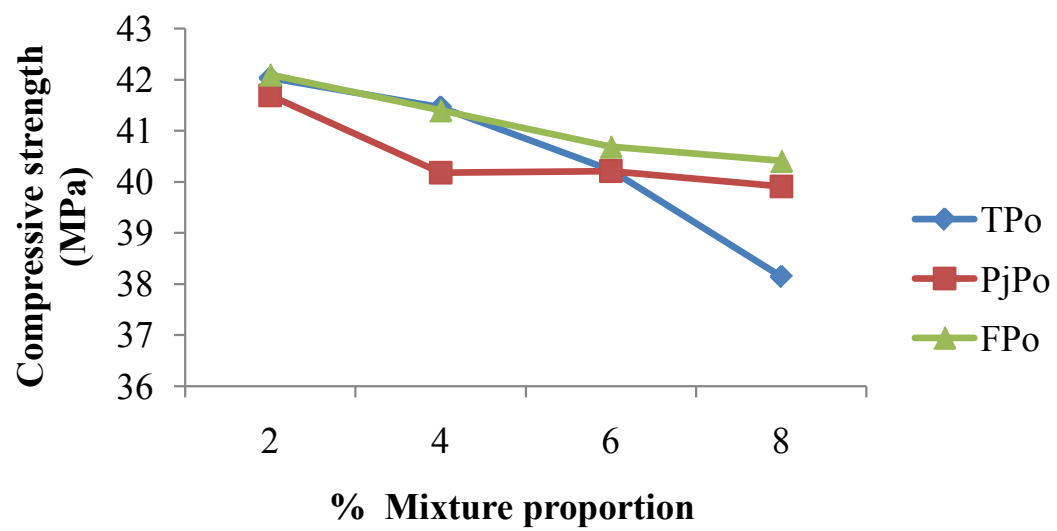

Figure 12. Compressive strength obtained at 28 days for different pozzolans studied.

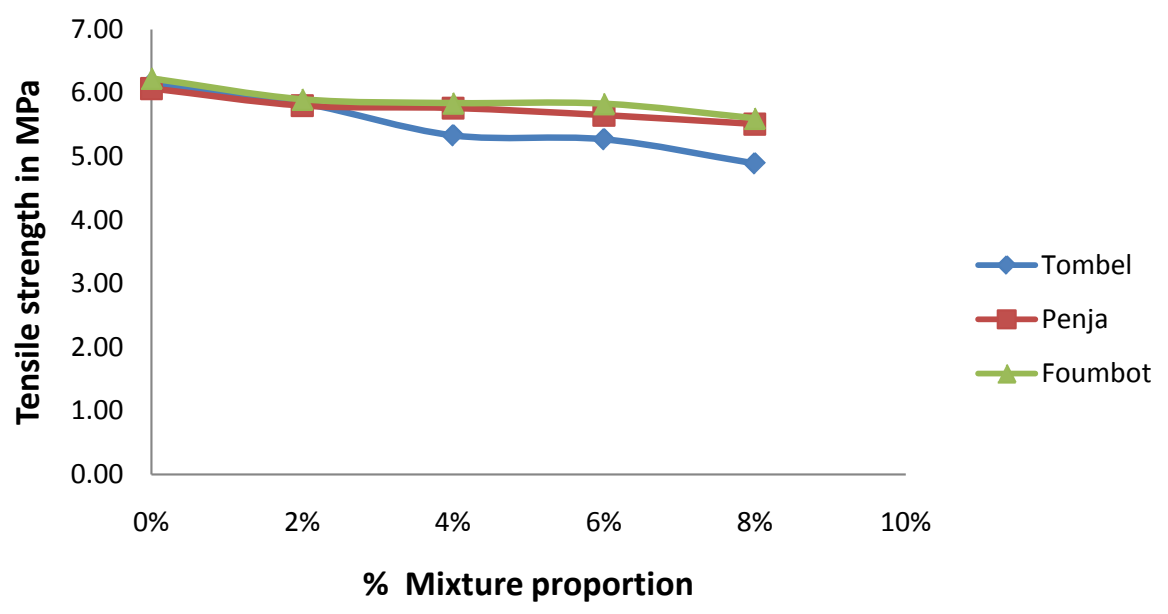

Figure 13. Tensile strength obtained at 28 days for different pozzolans studied.

For all pozzolans studied the compressive and tensile strength decrease with the rate of addition of the pozzolan. For an addition of $2 \%$ to $6 \%$ of pozzolans, the compressive strengths of the mortars are greater than $40 \mathrm{MPa}$. Beyond $6 \%$ of addition it is noted that only the resistance of the mortars made from Foumbot black pozzolana remains higher than $40 \mathrm{MPa}$. The black pozolane from Penja is 
slightly lower than $40 \mathrm{MPa}$ and the strength of black pozzolan from Tombel remains below $40 \mathrm{MPa}$. Then, it is noted that Foumbot black pozzolan has better results of mechanical strength. This is due to the fact that it contains a highest percentage of $\mathrm{SiO}_{2}$ (55\%) followed by the Penjapozzolan (44\%). In addition, it is noted that the highest specific surface and the highest activity index is obtained with an addition of black pozzolan from Foumbot, followed by black pozzolan from Penja and black pozzolan from Tombel.

\section{Conclusions}

- The activity index shows that all the pozzolans studied present pozzolanic properties and can therefore be used as an addition in the manufacturing of cement.

- The highest specific surface and the highest activity index are obtained with an addition of black pozzolan from Foumbot, followed by black pozzolan from Penja and black pozzolan from Tombel.

- Foumbot black pozzolan has better results of mechanical strength. This is due to the fact that it contains a highest percentage of $\mathrm{SiO}_{2}(55 \%)$ followed by the Penjapozzolan (44\%).

- The mechanical strengths of cements decrease with the percentage of pozzolans addition.

- Cement made up with an addition of $2 \%$ to $6 \%$ of black pozzolan from Penja has strengths greater than $40 \mathrm{MPa}$ at 28 days.

- Cement made up with an addition of $2 \%$ to $4 \%$ black pozzolan from Tombel has strengths greater than $40 \mathrm{MPa}$ at 28 days.

- The cement manufactured with an addition of $2 \%$ to $8 \%$ of black pozzolan from Foumbot has resistances greater than $40 \mathrm{MPa}$ at 28 days.

\section{Confirm}

The authors also confirm that in this paper:

- Acknowledgements is not applicable.

- Competing interests: The authors declare that they have no competing interests.

- Availability of data and materials is not applicable.

- Consent for publication is not applicable.

- Ethics approval and consent to participate is not applicable.

- Funding is not applicable.

- No data were used to support this study.

The data used to support the findings of this study are available from the corresponding author upon request.

\section{Conflicts of Interest}

The authors certify that there's no financial/personal interest or belief that could affect their objectivity and there is no conflict of interest. 


\section{References}

[1] Drissi, M., Mezghiche, B. and Khouadjia, M.L.K. (2015) Influence of Concrete Composition Parameters on Its Compressive Strength. Courrier du Savoir, 20, 73-78.

[2] Mokhtaria, B., Fatiha, K.A. and Abdelaziz, S. (2009) Durability of Mortars Based on Natural Pozzolana and Artificial Pozzolana. Nature and Technology Review, 1, 63-73.

[3] Elke, G. (2012) Investigation of the Influence of Blast-Furnace Slag on the Resistance of Concrete against Organicacid or Sulphate Attack by Means of Accelerated Degradation Tests. Cement and Concrete Research, 42, 173-185. https://doi.org/10.1016/j.cemconres.2011.09.009

[4] Mahsa, M.H., Shao, Y.X. and Whalen, J.K. (2011) Biocement Production from Silicon-Rich Plant Residues: Perspectives and Future Potential in Canada. Biosystems Engineering, 110, 351-362.

[5] Cheriaf, M., Cavalcante Rocha, J. and Péra, J. (1999) Pozzolanic Properties of Pulverized Coal Combustion Bottom Ash, Cement. Concrete Research, 29, 1387-1391. https://doi.org/10.1016/S0008-8846(99)00098-8

[6] Gumma, M.A. and Mohamed, A.A. (2016) The Effect of Jebel Marra Natural Pozzolona on the Strength and Permeability of Mortar. Imperial Journal of Interdisciplinary Research, 2, 341-348.

[7] Mbessa, M., Ndongo, E.C., Nga, H.N. and Tatietse, T.T. (2012) Influence of the Powder of Pozzolana on Some Properties of the Concrete: Case of the Pozzolana of Djoungolo (Cameroon). International Journal of Modem Engineering Research, 2, 4162-4165.

[8] Tchamdjou, W.H.J., Grigoletto, S., Grigoletto, S., Michel, F. Courard, L., Abidi, M.L. and Cherradi, T. (2017) An Investigation on the Use of Coarse Volcanic Scoria as Sand in Portland Cement Mortar. Case Study in Construction Materials, 7, 191-206.

[9] Kamseu, E., Leonelli, C., Pereira, D.S., Melo, U.C. and Lemougna, P.N. (2009) Investigation of Volcanic Ash-Based Geopolymers as Potential Building Materials. International Ceramic Review, 58, 136-140.

[10] Nkouathio, D.G., Kagou Dongmo, A., Bardintzeff, J.M., Wandji, P., Bellon, H. and Pouclet, A. (2008) Evolution of Volcanism in Graben and Horst Structures along the Cenozoic Cameroon Line (Africa): Implications for Tectonic Evolution and Mantle Source Composition. Mineralogy and Petrology, 94, 287-303. https://doi.org/10.1007/s00710-008-0018-1

[11] Billong, N., Melo, U.C., Njopwouo, D., Louvet, F. and Bonnet, J.P. (2013) Physicochemical Characteristics of Some Cameroonian Pozzolans for Use in Sustainable Cement Like Materials. Materials Sciences and Applications, 4, 14-21. https://doi.org/10.4236/msa.2013.41003

[12] Tsafack, J.P.F., Wandji, P., Bardintzeff, J.M. and Bellon, H. (2009) The Mount Cameroon Stratovolcano (Cameroon Volcanic Line, Central Africa): Petrology, Geochemistry, Isotope and Age Data. Geochemistry, Mineralogy and Petrology, 47, 65-78.

[13] Demirdag, S., Ugur, I. and Sarac, S. (2008) The Effects of Cement/Fly Ash Ratios on the Volcanic Slag Aggregate Lightweight Concrete Masonry Units. Construction and Building Materials, 22, 1730-1735.

https://doi.org/10.1016/j.conbuildmat.2007.05.011 
[14] Kaid, N., Cyr, M., Julien, S. and Khelafi, H. (2009) Durability of Concrete Containing a Natural Pozzolan as Defined by a Performance-Based Approach. Construction and Building Materials, 23, 3457-3467.

https://doi.org/10.1016/j.conbuildmat.2009.08.002

[15] Siddique, R. (2011) Effect of Volcanic Ash on the Properties of Cement Paste and Mortar. Resources, Conservation and Recycling, 56, 66-70. https://doi.org/10.1016/j.resconrec.2011.09.005

[16] Tchakouté, H.K., Elimbi, A., Yanne, E. and Djangang, C.N. (2013) Utilization of Volcanic Ashes for the Production of Geopolymers Cured at Ambient Temperature. Cement and Concrete Composites, 38, 75-81. https://doi.org/10.1016/j.cemconcomp.2013.03.010

[17] Celik, K., Meral, C., Mancio, M., Mehta, P., Kumar, M. and Paulo, J.M. (2014) A Comparative Study of Self-Consolidating Concretes Incorporating High-Volume Naturalpozzolan or High-Volume Fly Ash. Construction and Building Materials, 67, 14-19. https://doi.org/10.1016/j.conbuildmat.2013.11.065

[18] Kilic, A. and Sertabipoglu, Z. (2015) Effect of Heat Treatment on Pozzolanic Activity of Volcanic Pumice Used as Cementitious Material. Cement and Concrete Composites, 57, 128-132. https://doi.org/10.1016/j.cemconcomp.2014.12.006

[19] Yankwa Djobo, J.N., Antoine, E., Hervé Kouamo, T. and Sanjay, K. (2016) Mechanical Properties and Durability of Volcanic Ash Based Geopolymer Mortars. Construction and Building Materials, 124, 606-614. https://doi.org/10.1016/j.conbuildmat.2016.07.141

[20] Zhang, P., Huang, J., Shen, Z., Wang, X., Luo, F., Zhang, P., Wang, J. and Miao, S. (2017) Fired Hollow Clay Bricks Manufactured from Black Cotton Soils and Natural Pozzolans in Kenya. Construction and Building Materials, 141, 435-441. https://doi.org/10.1016/j.conbuildmat.2017.03.018

[21] Yankwa Djobo, J.N., Antoine, E., Hervé Kouamo, T. and Sanjay, K. (2017) Volcanic Ash-Based Geopolymer Cements/Concretes: The Current State of the Art and Perspectives. Environmental Science and Pollution Research, 24, 4433-4446. https://doi.org/10.1007/s11356-016-8230-8

[22] Kupwade-Patil, K., et al. (2018) Impact of Embodied Energy on Materials/Buildings with Partial Replacement of Ordinary Portland Cement (OPC) by Natural Pozzolanic Volcanic Ash. Journal of Cleaner Production, 177, 547-554. https://doi.org/10.1016/j.jclepro.2017.12.234

[23] Lemougna, P.N., et al. (2018) Review on the Use of Volcanic Ashes for Engineering Applications. Resources, Conservation \& Recycling, 137, 177-190. https://doi.org/10.1016/j.resconrec.2018.05.031

[24] ASTM C150-07-Standard Specification for Portland Cement.

[25] ASTM C 128-Standard Test Method for Relative Density (Specific Gravity) and Absorption of Fine Aggregate.

[26] ASTM C618-Standard Specification for Coal Fly Ash and Raw or Calcined Natural Pozzolan for Usein Concrete.

[27] EN 196-1 Test Methods for Cements Part 1: Determination of Resistance.

[28] EN 196-3 Testing Methods for Cements Part 3: Determination of Setting Time and Stability. 